\title{
Media Exposure as Political Participation Predictor of Young Voters in Presidential Election 2019
}

\author{
$1^{\text {st }}$ Muhammad Wahyu Kuncoro* \\ Faculty of Psychology \\ Gadjah Mada University \\ Yogyakarta, Indonesia \\ wahyu.kuncoro.m@mail.ugm.ac.id
}

\author{
$2^{\text {nd }}$ Koentjoro \\ Faculty of Psychology \\ Gadjah Mada University \\ Yogyakarta, Indonesia \\ koentjoro@ugm.ac.id
}

\author{
$3^{\text {rd }}$ Arie Sujito \\ Faculty of Social and Political Sciences \\ Gadjah Mada University \\ Yogyakarta, Indonesia \\ djitoarie@ugm.ac.id
}

\begin{abstract}
Citizen's participation in elections is very important in democratic country. In general, this study examines the role of political information exposure from media and political efficacy to political participation of young people in the Indonesian presidential election in 2019. The data were collected by using 3 scales, namely political information exposure, political efficacy scale, and political participation scale. The research sample were 466 undergraduate students, aged between 17 to 21 years old who are being resident in Yogyakarta. The data were analyzed using the Smart Partial Least Square (PLS). The results of the study showed that the political information exposure from media and political efficacy contributed directly to the political participation of young people. The political information exposure also influenced indirectly to political participation through political efficacy.
\end{abstract}

Keywords-Political participation, political efficacy, political media exposure, and young voters

\section{INTRODUCTION}

\section{A. Civic culture and political participation of young voters}

A political system will run well if it is supported by a political culture that is in harmony with the established political system. There is a strong relationship between citizens, democratic values and political participation. People who believe that voting and participation in politics bring change will encourage them to take part in political life. Likewise, if someone has a political efficacy belief that the government responds to demands and needs, or participation in politics has influence in political processes, then more participation in politics [1]

General elections are one of the important political processes for the Indonesian state that adheres to the political system of democracy. The issue of participation in elections in Indonesia includes the level of participation which tends to decrease after the political reforms from 1998[2]. One group of voters who are considered vulnerable to contributing to the low level of participation in elections is the young voters, those with age range from 17 to 21 years.

In a psychological perspective, young voters are in transition from late adolescence to early adulthood. A prominent figure in social development psychology, Erik Erikson [3] included age 17-21 years into the developmental stage of "identity versus confusion of identity". At this stage, a teenager is faced with the question of who they are, who they really are and where they will go in their life.
Furthermore, at the end of this stage of development, a teenager is expected to have succeeded in having an integrated identity.

This identity is needed to answer the demands of social roles at the next stage of development, namely the phase of "intimacy versus isolation". At this stage, adults are expected to be able to establish good working relationships, form friendships with other people, and feel connectedness with their community. A teenager who does not succeed in achieving an identity can fail in building intimacy with others.

How important is young voter participation in elections in Indonesia? Participation in elections can be a reference for their behavior when they become adults, as a form of responsibility and commitment to their social role. The election agenda can be a good opportunity for young voters to do experiment with roles and personalities in ways that are good and in harmony with existing social values. The scope of political participation in this study focused on the general election participation of the president and vice president of Indonesia in 2019.

\section{B. Political participation}

Political participation is an activity that has an intention or impact to influence government actions, both direct influence in making and implementing public policies or indirectly in the selection of people who make these policies [4]. According to David Easton, political participation can be seen from the concept of support for political systems, namely diffuse support and specific support, where in concrete manifestations show different objects of support [5]. Diffuse support is more directed to the fundamental aspects of the political system, such as the constitutional order and political institutions in general. Whereas specific support is more directed at supporting political authority holders or related to the performance or output produced.

Huntington \& Nelson [6] divided forms of political participation into: a) electoral activities, b) lobbying, c) contacting, and d) violence. There are differences in measurement of political participation used by researchers, for example: Mcleod et al. [7] measuring political participation by combining voting activities, contacting public officials, and talking about local issues in public forums; while Yang \& Dehart [8] use online political participation. Participation that reveals election activities is based on a single activity, namely voting. Therefore, in this study the scope of early voter participation in elections will be discussed using an approach from David Easton [9], 
where political activity can be divided into diffuse support and specific support [5].

\section{Antecedents of political participation}

There are various theoretical perspectives to explain the factors that influence political participation. This study will use the perspective of political socialization and psychological perspective. Political socialization is defined as the development of mental processes where adolescents acquire cognitions, attitudes, and behaviors related to their political environment said by Atkin \& Gantz [10].

According to Plutzer, an important period in the developmental stage between the ages of children and adults are a period of formation of political attitudes and behavior as citizens [11]. Political learning is influenced by various socialization agents such as family, peer, school, mass media, and political situations [11]. This study will focus on the role of media as agent of political socialization for young voters.

The media as a channel to convey things that have been known and done by the previous generation to the new generation. Young people interact directly with messages that have been constructed by the media. News and commentary from newspapers, magazines, and televisions. Through watching television and reading newspaper on news about the world of politics, young people become more acquainted with political figures and develop political knowledge and attitudes [12,13].

According to Yamamoto, Kushin, \& Dalisay [14] social media sites such as Facebook, Twitter, YouTube, and blogs give users the opportunity to obtain political information and interact to have political experiences. Users get political information through comments on blogs, videos, audio, photos uploaded by other users. Consumption of political information and political expression online is related to the formation of cognitive aspects, attitudes, and political behavior.

Psychological perspectives explain that political participation is influenced by psychological determinants such as cognitive characteristics (political interest \& political knowledge), cognitive abilities (party identification \& ideology), and personality characteristics. In this study the psychological determinant used is political efficacy.

\section{1) Media exposure}

Media is the main channels where a number of people receive information and entertainment, namely through television, radio, newspapers, and the internet [15]. According to Marshall McLuhan [16] media is a tool for self-expansion. Furthermore, mass media is a kind of media that can be seen as a meeting between mass communication, culture, and technology. In this case, televisions, newspapers and magazines are included.

Mass media, both conventional and modern, provide a lot of information to the public, including political information. Many political parties have used mass media and social media as a means to convey messages.

Based on the view of social learning theory from Bandura [17], political activities delivered through information media can be the object of observation for adolescents. When adolescents make imitation (imitation) and then get reinforcement (reinforcement) from the environment, then, more and more, new political behavior is formed. The imitation process without the emphasis of attitude can be a powerful force of socialization. Socialization by giving examples will look more important than socialization in other ways [18].

The results of Kim \& Chen study [19] show there is a direct role of political information from the internet (blogs, social networks) on the political participation of young voters in the United States.

\section{2) Political efficacy}

Bandura defined political efficacy as a self-belief that individuals are able to influence the political system [20]. Whereas Campbell, Gurin, and Miller [21] defined political efficacy as a feeling that political and social change as possibility, and individual citizens can play a role in these changes.

Furthermore, Bandura [20] explained that individual beliefs to be able to influence the political system consist of two aspects. The first aspect is the belief that he can produce effective efforts by utilizing his abilities and resources. The second aspect is the belief that changes in the political system are related to the efforts that have been made. More specifically, some figures divide political efficacy into two different constructs, namely internal political efficacy and external ones[22]. Internal political efficacy is a person's belief in his or her own ability to understand and to participate effectively in politics, while external political efficacy is the extent to which a person perceives that the government is responsive to community demands [21]. Someone who has high political efficacy, tends to show a higher level of political participation.

Previous studies have been conducted to examine the role of political efficacy on political participation. For example, Niemi et al. [22] revealed that there is a positive relationship between political efficacy (internal and external) to political participation in a general election study in the United States. The same results are also shown by Wollman \& Stouder [23], that there is an influence of political efficacy on political participation (voting, campaigns, contact with politicians) on students in Washington.

Klemmensen et al. [1] found political efficacy as astrong predictor of students' political participation in cross-cultural studies in Denmark (the form of participation: present in voting, never avoiding taxes; always obeying laws and regulations; monitoring government actions; active in social or political associations ; trying to understand the reasons for other people who are different), furthermore in the United States (the form of participation: signing a petition; boycotting or intentionally buying a particular product for political, ethical or environmental reasons; participating in demonstrations; attending political meetings or public meetings; donating money for social or political activities; joining political discussion forums on the internet; participating in environmental activities.

The same results are shown by Cohen et al. [4] that political efficacy has a significant contribution to political participation in northern Israeli citizens. Furthermore, Jordan, Pope, Wallis, \& Iyer [24] find political efficacy to have a significant role in online political activity among students in Canada. The study conducted by Cohen et al. [4] 
and Anderson [25] showed that political efficacy is a good predictor of political participation.

According to Almond \& Verba [26] political culture develops and is influenced by the interaction of values in society. Community members experience, absorb, and live the political values around them. These processes are called political socialization, the growth and development of political culture is the result (output) of political socialization.

Herbert Hyman explained political socialization is a process in which institutions instill political values to be maintained from generation to generation so as to create political system stability [27]. The family and the media are part of political socialization agents that positively influence political participation in adolescents [28].

Hypothesis 1: there is a positive correlation between political efficacy and diffuse support political participation

Hypothesis 2: there is a positive correlation between political efficacy and specific support political participation

\section{3) Political information and political participation}

According to Marshall McLuhan [16] the media is a tool for self-expansion. The media is basically empty, until we perceive some form of content which is then interpreted as a message. Further explained, mass media is a kind of media that can be seen as a meeting between mass communication, culture, and technology. In this case television, newspapers and magazines are included.

The media is one of the important agents in political socialization [27,29]. Mass media can be a very important political socialization tool, because young people can get political information directly without going through family and school, so that it can influence political values, opinions and attitudes [30,31].

The theory of social cognition is based on Bandura's concept of observational learning. The theory of social cognition provides an explanation of how a behavior can be formed through observation of the models that appear in the mass media. Observers see the consequences of the behavior displayed by the model, whether getting reward or punishment. In addition, the observer can also learn from observing others who imitate the behavior of the model, whether it is able to imitate (efficacy) and what effects it has [32]. In the context of elections, beginner voters get various information from the media regarding election-related news.

Media system dependency theory is stated by BallRokeach [32] who explains that there are three parties, namely: the media, the audience, and the community that are interdependent. Achievement of objectives on the one hand depends on the availability of the resources of the other party. At present, the media has an important role to oversee the democratic process, on the one hand the media has the resources to present actual and objective information related to the activities of holding elections, and on the other hand, the audience is very in need of information from the media to understand the ongoing political realities, as well as the social (community) system which has an electoral agenda that can be achieved if the media and the voters support it.

Hypothesis 3: there is a positive correlation between media exposure and diffuse support political participation
Hypothesis 4: there is a positive correlation between media exposure and specific support political participation

\section{4) Media exposure and political efficacy}

The internet can increase internal efficacy by providing information that can be accessed by citizens. Cornfield [21] argues that the Internet can increase the efficacy of internal politics by making people less embarrassed by their political competence, because someone can make comments anonymously so as to reduce the fear of public embarrassment. The internet also provides new and cheaper ways in which an individual can participate in politics, for example sending aspirations via e-mail to the presidential and vice-presidential spouses or contributing to campaigns.

The internet can also increase the efficacy of external politics because it allows citizens to interact with public officials and hold them accountable, get responses to messages delivered via email or forums on the internet.

Based on the description above it can be concluded that political information obtained through mass media (conventional \& internet) and social media can increase the political efficacy of citizens.

Hypothesis 5: there is a positive correlation between media exposure and political efficacy.

\section{METHODS}

The research variables involved in this study were political information exposure, political efficacy, and political participation. The research subjects were beginner voters who had the right to give political rights and reside in Yogyakarta. The number of research subjects was 466 students aged 17-21 years who came from various regions in Indonesia.

Political participation was measured in different form of political participation, namely diffuse support activities and specific support activities. The diffuse support activity was measured by the scale of political participation-diffuse support consists of 8 questions (alpha $=0.86$ ), while the specific support activities was measured by the scale of political participation-specific support consists 9 questions $($ alpha $=0.92)$. Examples of questions such as: "How often do your parents attend meetings in the community, how often parents invite you to discuss political issues".

Political efficacy is defined as one's self-confidence that he is able to use the competencies and resources possessed to carry out political activities, as well as the belief that his efforts affect the political system. Political efficacy was revealed using a scale of political efficacy (reliability of alpha $=0.879)$ consisting of internal and external political efficacy [33] totaling 8 items. Examples of questions such as: "I believe that I am able to understand political issues in our country at this time, I believe that my vote in the election will contribute to the victory of one of the presidential candidates".

The scale of exposure to media political information is measured using questions based on the concept of [34], namely: obtaining political information (about the presidential and vice-presidential pair and party, election administration) from television, newspapers, radio, news media internet, social media. Consists of 15 questions (alpha 
$=0.89)$. PLS (Partial Least Square) program to test the predictive model of political participation.

\section{RESULTS}

The test results of the predictive model of political participation are shown in the following figure 1 :

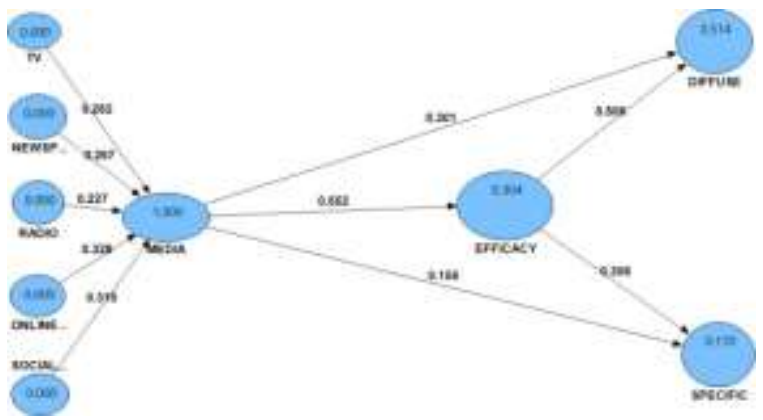

Fig. 1. Political participation predictive model

The path coefficient of relationships between variables can be seen in the following table 1 :

TABLE I. TABLE PATH COEFFICIENT

\begin{tabular}{|l|c|c|}
\hline \multicolumn{1}{|c|}{$\begin{array}{c}\text { Variabe } \\
\text { ls }\end{array}$} & $\begin{array}{c}\text { Original } \\
\text { sample (O) }\end{array}$ & $\begin{array}{c}\text { T- } \\
\text { Statistics* }\end{array}$ \\
\hline Media exposure) $\rightarrow$ Diffuse support & 0,301 & 7,271 \\
\hline Media exposure $\rightarrow$ Specific support & 0,155 & 2,964 \\
\hline Media exposure $\rightarrow$ Political efficacy & 0,552 & 14,848 \\
Political efficacy $\rightarrow$ Diffuse support & 0,506 & 11,833 \\
\hline Political efficacy $\rightarrow$ Specific support & 0,306 & 6,432 \\
\hline Gender $\rightarrow$ Political participation & $-0,216$ & 2,909 \\
\hline
\end{tabular}

a. *T-Statistic sign > 1,96; Gender : male is coded 1 \& female is coded

The Table 1 above shows that the relationship between media exposure and diffuse support is significant with a $\mathrm{T}$ statistic of 7.271 (> 1.96). The original sample estimate value is positive which is equal to 0.301 which indicates that the direction of the relationship between Media exposure and diffuse support is positive. Thus hypothesis 3 in this study which states that media exposure affects diffuse support political participation was accepted.

In Table 1, it is shown that the relationship between media exposure and specific support is significant with a $\mathrm{T}$ statistic of 2.964 (> 1.96). The original sample estimate value is positive which is equal to 0.155 which indicates that the direction of the relationship between media exposure and political is positive. Thus hypothesis 4 in this study which states that media exposure affects specific support political participation accepted.

Table 1 above also shows that the relationship between media exposure and political efficacy is significant with a $\mathrm{T}$ statistic of 14.848 ( $>1.96)$. The original sample estimate value is positive which is equal to 0.552 which indicates that the direction of the relationship between media exposure and political efficacy is positive. Thus hypothesis 5 in this study which states that media exposure affects political efficacy accepted.

The total effect of media exposure on political participation is $0.590 \mathrm{~T}$-statistics 13.333 . The results of the mediation test using the Variance Accounted For (VAF) method obtained a score $=0.248(24.8 \%)$ included in the category of partial mediation.

The results of the analysis showed that the relationship between gender and political participation is significant with T-Statistics of 2.99 (> 1.96). The original sample estimate value is equal to -0.276 which indicates that the direction of the relationship between gender and political participation is negative (men are coded 1; women are coded 2 ). The mean perception score of political activity in men $=40.49(\mathrm{~N}=$ $142)$, while in women $=40.32(\mathrm{~N}=324)$. The difference test results showed a score of $t=0.163(\mathrm{p}>0.05)$. The average score of political participation in men $=51.88(\mathrm{~N}=142)$, while in women $=43.16(\mathrm{~N}=324)$. The test results of differences in the score of political participation showed a score of $\mathrm{t}=50.75(\mathrm{p}<0.01)$.

\section{DISCUSSIONS}

The results indicate that exposure to media information has a direct influence on the political efficacy of young voters. Young voters who get political information about elections from various media, tend to have confidence that they are able to understand issues about politics, feel able to participate in political activities, and believe that the voting (voting) that is given will also influence the victory of the candidate they support.

The results of this study are in line with the findings of several previous studies. For example, research conducted by Cornfield [21] suggests that the internet can improve the effectiveness of internal politics by making people less embarrassed by their political competence, because someone can make comments anonymously so as to reduce the fear of public embarrassment. The internet also provides new and cheaper ways in which an individual can participate in politics, for example, sending aspirations by e-mail to the presidential and vice-presidential spouses or contributing to campaigns. The internet can increase internal efficacy by providing information that can be accessed by citizens. Internet media can also increase the efficacy of external politics because it allows citizens to interact with public officials and hold them accountable, get responses to messages conveyed via email or forums on theinternet.

Other results also show relatively similar findings, namely the use of online news media and newspapers that are positively correlated with political efficacy in adolescents $[14,35,37]$. Exposure to political media information obtained through mass media (conventional \& internet) and social media can increase the political efficacy of citizens.

The agenda setting theory presented by McComb states that the mass media has the ability to transfer something that is on the agenda in reporting to the public agenda [38]. In Indonesia, the media plays a large role in the democratic process, so it is often referred to as the fourth pillar of democracy because it is considered capable of being a tool to convey public aspirations [39]. One party that uses the media is political actors, where they can establish communication with a wide range of audiences. After the development of the internet, many ordinary people also use social media to communicate their aspirations, support, and comments related to various things [40].

Mass media, both conventional and modern, provide a lot of information to the public, including political information. 
Many parties have used mass media and social media as a means to convey messages.

Based on the view of social learning theory [17] political activities delivered through information media can be the object of observation for adolescents. When adolescents make imitation (imitation) and then get reinforcement (reinforcement) from the environment, then more and more new political behavior is formed. The imitation process without the emphasis of attitude can be a powerful socialization power. Socialization by giving examples will look more important than socialization in other ways [18]. The results of previous studies show there is a direct role of political information from the internet (blogs, social networks) on the political participation of beginner voters $[19,41]$.

Quantitative analysis results show that political efficacy has a direct influence on political participation of beginner voters, both diffuse support and specific support. The results of this study are consistent with the findings of previous studies which stated that there was an influence of political efficacy on political participation $[8,24,42,45]$.

This is in line with the theoretical concept of Bandura [20] which explains self-efficacy as an individual's selfassessment of his ability to organize and carry out the actions needed to achieve the desired goals. Individuals with high self-efficacy focus more on the opportunities they deserve and believe that obstacles can be overcome. Individuals with low self-efficacy have self-doubt and believe that they have little control over obstacles and often convince themselves that their efforts will be ineffective. Based on that Bandura's perspective, self-assessment of individual abilities can determine whether someone will be involved in a new task or not, for example participating in politics.

The political efficacy of subjects also contributed significantly to political participation. The higher the political efficacy of adolescents the higher their political participation. This finding having same results that shown by Cohen et al. [4] that political efficacy has a significant contribution to political participation in northern Israeli citizens. It is also similar to the research conducted by Jordan, Pope, Wallis, \& Iyer (2015) find political efficacy to have a significant role in online political activity among students in Canada.

The results of this study also showed that the age factor was positively correlated with the political participation of beginner voters. This finding is in line with the results of research conducted by Quintelier [46]. Young voters tend to be low in voting behavior, and will increase with age to adulthood, and decrease in old age as they begin to move away from social life. In this research, the gender is also having influence to political participation. In general, men tend to exhibit higher voting behavior, due to differences in roles in society. According to Welch [47] one of the factors that influence political participation is gender differences which are moderated by differences in structural and situational aspects. Structural aspects include age, level of education, income (income) and region, while situational aspects include marital status, number of young children and work outside the city.

\section{CONCLUSION}

All hypothesis were proven by data from the research field. The political media exposure has a positive influence on political participation. Media exposure has both a direct impact to political participation and indirect impact through political efficacy. In addition, gender has a role in the strength of the relationship of media exposure and political participation.

\section{REFERENCES}

[1] R. Klemmensen et al., "The genetics of political participation, civic duty, and political efficacy across cultures: Denmark and the United States," J. Theor. Polit., vol. 24, no. 3, pp. 409-427,2012.

[2] M. Asfar, Presiden golput. Surabaya: Jawa Pos Press, 2004.

[3] J. W. Santrock, Adolesence perkembangan remaja, Edisi VI. Jakarta: Penerbit Erlangga, 2003.

[4] A. Cohen, E. Vigoda, and A. Samorly, "Analysis of the mediating effect of personal-psychological variables on the relationship between socioeconomic status and political participation: A structural equations framework," Polit. Psychol., vol. 22, no. 4, 2001

[5] D. Easton, "A re-assessment of the concept of political support," Br. J. Polit. Sci., vol. 5, no. 4, pp. 435-457, 1975.

[6] S. P. Huntington and J. Nelson, Partisipasi politik di negara berkembang. Jakarta: Rineka Cipta, 1994.

[7] J. M. Mcleod, D. A. Scheufele, and P. Moy, "Community, communication, and participation: The role of mass media and interpersonal discussion in local political participation," Polit. Commun., no. August 2013, pp. 37-41, 2010.

[8] H. C. Yang and J. L. Dehart, "Social media use and online political participation among college students during the US election 2012," Soc. Media+ Soc., vol. 2, no. 1, 2016.

[9] D. Easton, "An approach to the analysis if political systems," World Polit., vol. 9, no. 3, pp. 383-400, 1957.

[10] J. Pasek, L. Feldman, D. Romer, and K. H. Jamieson, "Schools as incubators of democratic participation: Building long-term political efficacy with civic education," Appl. Dev. Sci., vol. 12, no. 1, pp. 2637, 2008.

[11] K. Smets and C. Van Ham, "The embarrassment of riches ? A metaanalysis of individual-level research on voter turnout," Elect. Stud., pp. 1-16, 2013.

[12] J. M. . McLeod, "Media and civic socialization of youth," J. Adolesc. Heal., vol. 27, no. 2, pp. 45-51, 2000.

[13] B. R. Warren and R. H. Wicks, "Political socialization: Modeling teen political and civic engagement," Journal. Mass Commun. Q., vol. 88, no. 1, pp. 156-175, 2011.

[14] M. Yamamoto, M. J. Kushin, and F. Dalisay, "Social media and mobiles as political mobilization forces for young adults: Examining the moderating role of online political expression in political participation," New Media Soc., vol. 17, no. 6, pp. 880-898,2014.

[15] A. S. Hornby, Oxford advanced learner's dictionary. New York: Oxford University Press, 2010.

[16] D. Giles, Media psychology. New Jersey: Lawrence Erlbaum Associates, Inc, 2003.

[17] A. Bandura, Social learning theory. USA: Prentice Hall, 1977.

[18] V. Chansilp, "Participation in student goverment and students' sense of political efficacy of four Thai high school," (Doctoral dissertation, University of Southern California), 1994.

[19] Y. Kim and H.-T. Chen, "Telematics and informatics social media and online political participation: The mediating role of exposure to cross-cutting and like-minded perspectives," Telemat. informatics, vol. 33, no. 2, pp. 320-330, 2016.

[20] A. Bandura, Self-efficacy the exercise of control. New York: W.H. Freeman \& Company, 1997.

[21] K. Kenski and N. J. Stroud, "Connections between internet use and political efficacy, knowledge , and participation," J. Broadcast. Electron. Media, vol. 50, no. June, pp. 173-192, 2006.

[22] R. G. Niemi, S. C. . Craig, and F. Mattei, "Measuring internal political efficacy in the 1988 national election study," Am. Polit. Sci. Rev., vol. 85, no. 4, pp. 1407-1413, 1991. 
[23] N. Wollman and R. Stouder, "Believed efficacy and political activity a test of the specificity hypothesis," J. Soc. Psychol., vol. 131, no. 4, pp. 557-566, 1990.

[24] G. Jordan, M. Pope, P. Wallis, and S. Iyer, "The relationship between openness to experience and willingness to engage in online political participation is influenced by news consumption," Soc. Sci. Comput. Rev., vol. 33, no. 2, pp. 181-197, 2015.

[25] M. R. Anderson, "Community psychology, political efficacy, and trust,” Polit. Psychol., vol. 31, no. 1, pp. 59-84, 2010.

[26] G. A. Almond and S. Verba, The civic culture: Political attitudes and democracy in five nations. USA: SAGE Publications Ltd, 1989.

[27] R. M. Merelman, "The adolescence of political socialization," Sociol. Educ., vol. 45, no. 2, pp. 134-166, 1972.

[28] E. Quintelier, "Engaging adolescents in politics: The longitudinal effect of political socialization agents," Youth Soc., vol. 47, no. 1, pp. 51-69, 2015.

[29] J. Dennis, "Major problems of political socialization research," Midwest J. Polit. Sci., vol. 12, no. 1, pp. 85-114, 1968.

[30] K. P. Langton and M. K. Jennings, "Political socialization and the high school civics curriculum in the United States," Am. Polit. Sci. Rev., vol. 62, no. 3, pp. 852-867, 1968.

[31] R. G. Niemi and B. I. Sobieszek, "Political socialization," Annu. Rev. Sociol., vol. 3, no. 1977, pp. 209-233, 1977.

[32] K. Miller, Communication theories: perspectives, processes, and Contexts. New York: McGraw-Hill Higher Education, 2002.

[33] R. G. Niemi, S. C. Craig, and F. Mattei, "Measuring Internal Politica Efficacy in the 1988 National Election Study," Am. Polit. Sci. Rev. vol. 85 , no. 4,1991

[34] A. Kononova, S. Alhabash, and F. Cropp, "The role of media in the process of socialization to American politics among international students," Int. Commun. Gaz., vol. 73, no. 4, pp. 302-321, 2011.

[35] M. R. Mccluskey, S. Deshpande, D. V Shah, and D. M. Mcleod, "The efficacy gap and political participation: When political influence fails to meet expectations," Int. J. Public Opin. Res., vol. 16, no. 4, 2004.

[36] J. Moeller, C. De Vreese, F. Esser, and R. Kunz, "Pathway to political participation: The influence of online and offline news media on internal efficacy and turnout of first-time voters," Am. Behav. Sci., vol. 58, no. 5, pp. 689-700, 2014

[37] E. Quintelier, "The Effect of Internet Use on Political Participation An Analysis of Survey Results for 16-Year-Olds in Belgium," Soc. Sci. Comput. Rev., pp. 1-17, 2008.

[38] L. Camaj, "The consequences of attribute agenda-setting effects for political trust, participation, and protest behavior," J. Broadcast. Electron. Media, vol. 58, no. 4, pp. 634-654, 2014

[39] F. Junaedi, Komunikasi politik: Teori, aplikasi dan strategi di Indonesia. Yogyakarta: Buku Litera, 2013.

[40] A. G. William, Demokrasi di era digital, 1st ed. Yogyakarta: Pustaka Pelajar, 2000

[41] M. Barnidge, B. Sayre, and H. Rojas, "Perceptions of the media and the public and their effects on political participation in Colombia," Mass Commun. Soc., no. January 2015, pp. 37-41,2014.

[42] T. Kobayashi and M. Hoshimoto, "Does political participation make a difference? The relationship between political choice, civic engagement and political efficacy," Eleotoral Stud., vol. 27, pp. 7788, 2008.

[43] C. S. Park, "Pathways to expressive and collective participation: Usage patterns , political efficacy , and political participation in social networking sites," J. Broadcast. Electron. Media, vol. 59, no. 4, pp. 698-716, 2015.

[44] M. Vecchione, G. V. Caprara, M. G. Caprara, G. Alessandri, C. Tabernero, and J. L. González-, "The perceived political self-efficacy scale -short form (PPSE-S): A validation study in three Mediterranean countries," Cross-Cultural Res., vol. 48, no. 4, 2014.

[45] G. Wolfsfeld, "Political efficacy and political action: A change in focus using data from Israel," Soc. Sci. Q., 1979.

[46] E. Quintelier, "Differences in political participation between young and old people," Contemp. Polit., vol. 13, no. 2, pp. 37-41, 2007.

[47] S. Welch, "Women as political animals? A test of some explanations for male-female political participation," Am. J. Pol. Sci., vol. 21, no. 4, pp. 711-730, 1977. 